\title{
Muş Yemeklerinin Beslenme Antropolojisi Bağlamında Değerlendirilmesi*
}

\section{Evaluation of Muş Meals in the context of Nutritional Anthropology}

\author{
Mücahit Muslu ${ }^{a,{ }^{* *}}$, Funda Şensoy ${ }^{\mathrm{b}}$ \\ a Arş. Gör. İstanbul Arel Üniversitesi, Sağlık Bilimleri Yüksekokulu, Beslenme ve Diyetetik Bölümü, 34010, İstanbul/Türkiye. \\ ORCID: 000-0002-8761-5061 \\ b Dr. Dyt. Bağımsız Araştırmacı, 34744, İstanbul/Türkiye. \\ ORCID: 0000-0001-6880-410X
}

\begin{tabular}{l} 
MAKALE BİLGİSI \\
\hline Makale Geçmişi: \\
Başvuru Tarihi: 26 Kasım 2020 \\
Düzeltme Tarihi: 12 Aralık 2020 \\
Kabul Tarihi: 16 Aralık 2020 \\
\hline Anahtar Kelimeler: \\
Beslenme Antropolojisi \\
Muş Yemekleri \\
Beslenme Kültürü
\end{tabular}

\section{A R T I C L E IN F O}

\section{Article history:}

Received 26 November 2020

Received in revised form 12 December 2020

Accepted 16 December 2020

\author{
Keywords: \\ Nutrition Anthropology \\ Muş Dishes \\ Nutrition Culture
}

\section{ÖZ}

Bu çalışmanın amacı Muş ilinin coğrafi işaretli ve önemli geleneksel yemeklerinin beslenme antropolojisi açısından değerlendirilmesidir. Muş Çorti Turşusu, Muş Çorti Aşı, Muş Köftesi, Kaburga Dolması, Yumurtalı Kenger, Hazüt Dolması, Kırçikli Kelem Dolma, Cavbelek, Herse ve Kırçik yemekleri besin gruplarına ayrılarak incelenmiştir. Bölge mutfağı hayvancılık nedeniyle et ve süt ürünlerine dayanmaktadır. Tarımsal olarak en fazla üretilen buğday yemeklerin büyük çoğunluğunda kullanılmaktadır. Bölgede yetişen lahana sebze yemeklerinin başında gelmektedir. Özellikle kurutma ve salamura işlemleri sebzelerin kışa hazırlanması için kullanılmaktadır. Yemeklerin yapılışı ve isimleri bölgedeki eski medeniyetlerden izler taşımaktadır.

\section{Giriş}

Beslenme 'sağlığ korumak, geliştirmek ve yaşam kalitesini yükseltmek için vücudun gereksinimi olan besin ögelerini yeterli miktarlarda ve uygun zamanlarda almak için bilinçli yapılması gereken bir davranış' şeklinde tanımlanmaktadır (T.C. Sağlık Bakanlığı Halk Sağlığı Kurumu, 2016: 7). Günlük beslenmemiz et, süt, tahıl, sebze, meyve, yağ ve şeker gruplarından sağlanan besinlerle karşılanmaktadır. Bu besinlerin yeterli ve dengeli bir şekilde tüketilmesi sağlıklı bir yaşamın sürdürülmesi ve hastalıklardan korunmak için elzemdir (Baysal, 2017: 17). Beslenme sadece fizyolojik bir süreç olmayıp toplumları sosyokültürel alanlarda da etkilemektedir. Birçok toplumun beslenme ile ilişkili gelenek ve göreneklerinin yanında beslenme tabuları bulunmaktadır. Toplumdan topluma değişen bu davranışlar birçok faktörden etkilenmektedir. $\mathrm{Bu}$ faktörlerin incelenmesi için kültürel antropolojinin alt dalı olan ve insan ile beslenme arasındaki ilişkiyi inceleyen beslenme

* Bu çalışma, 22-23 Ekim 2020 tarihlerinde Muş Alparslan Üniversitesinde düzenlenen II. Uluslararası Muş Sempozyumunda sözlü bildiri olarak sunulmuştur.

** Sorumlu yazar/Corresponding author.

e-posta: dytmuslu@gmail.com 
antropolojisi bilim dalından faydalanılmaktadır (Merdol, 2015: 1-4).

Toplumların yaşamında beslenme ile ilgili konuların bilimsel bakış açısıyla incelenmesi yirminci yüzyılın başlarında başlamıştır (Ulijaszek ve Strickland, 1993). Özellikle Audrey Richards'ın 1932 yılında Bantu kabilesi ve 1939 yılında Bemba kabilesi üzerinde yaptığı açlık, beslenme ve tarım gibi konuları içeren toplumsal çalışmalar bu alanın öncüleri olmuştur. Bu çalışmalar ile toplumların beslenme kültürlerinin sosyal yaşamda birçok anlam taşıdığ1 görülmüştür (Richards, 1932; Richards, 1939). İkinci Dünya Savaşı sonrasında kıtlık ve açlık nedeniyle toplumsal sorunların artmasıyla beslenmenin toplumsal açıdan önemi ve sağlık açısından etkinliği daha çok anlaşılmış ve bu alanda çalışmalar arttırılmıştır. Özellikle gelişen sanayi ve işçi sınıfının büyümesi nedeniyle insanların besine ulaşımı ve ekonomik eşitsizlikler gündeme gelmiştir (Mead, 1970). Daha sonraki süreçte ise beslenme; evrimsel adaptasyon, çevre, ekoloji, sağlık sorunları, çevre sağlı̆̆ besin güvenliği, sosyopolitik konular gibi birçok alanla ilişkilendirilmiştir. Tüm bu çalışmalar beslenme antropolojisi biliminin genişlemesi ve bilimsel yöntemin oluşmasını sağlamıştır (Ulijaszek, 2018: 2). Beslenme antropolojisi oluşan bu yöntem ile sosyokültürel antropoloji alanının altında incelenip toplumlardaki beslenme ile ilgili durumlara bakarak toplumun besin tüketim ve beslenme durumlarını etkileyen biyolojik, sosyal, psikolojik, ekonomik, teknolojik, coğrafi, politik ve benzeri faktörleri ortaya çıkarmayı amaçlayan bir bilim dalı olmuştur (Merdol, 2015: 1-4). Bu bilim dalı ilgilendiği alanın genişliği nedeniyle birçok farklı bilim alanından yardım almaktadır. Arkeoloji biliminin sağladığı bulgular modern biyoteknoloji yöntemleri ile incelenerek o dönem insanlarının sağlik durumu yorumlanmakta veya bulunan kap kacak incelenerek o dönemde tüketilen besinler, besinlerin pişirilme şekilleri, besin saklama koşulları incelenebilmektedir. Aynı zamanda arkeolojik bulgulara bakılarak sosyal yaşamdan sanat anlayışına kadar birçok konuda yorum yapılabilmektedir. Günümüzde de beslenme antropolojisi aracılığıyla bir toplumun mutfağına bakarak o toplumun geçmişten günümüze geçirdiği süreçler ve bu sürecin beslenme tutumları üzerine etkisi hakkında yorum yapılabilmektedir (Ulijaszek, 2018: 1-9).

Muş, Doğu Anadolu Bölgesi'nin Yukarı Murat-Van

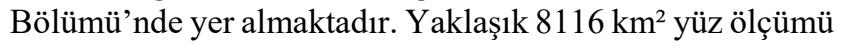
bulunmaktadır. Kuzeyde Erzurum, güney ve güneybatıda Bitlis, Diyarbakır ve Batman, batıda Bingöl ile doğuda Ağrı ve Bitlis illeriyle komşudur. Bölge 3000 metre yüksekliği geçmeyen engebeli dağlık araziler ve 1200-1500 metre yükseltideki ovalık arazilerden oluşmaktadır. Muş, gündüz ile gece arası sıcaklık farkının yüksek olduğu, donlu, soğuk ve uzun kışların geçtiği karasal iklim tipine sahiptir. Yıllık sıcaklıklar kışın ortalama $-10{ }^{\circ} \mathrm{C}$ yazın ise $25{ }^{\circ} \mathrm{C}$ 'nin üzerindedir. Yağış miktarı ise yıllık ortalama $765 \mathrm{~mm}$ 'dir (Sönmez, 2010: 45-46). Coğrafi ve iklimsel koşulları nedeniyle Muş ili özellikle sanayi ve konvansiyonel tarım alanında gelişememiştir. Muş Ovası'nda iklim şartları gereğince doğal tarım yöntemleriyle tahıl üretimi yapılmaktadır. Buna rağmen geniş bir düzlüğe sahip olan
Muş Ovası makinalı tarım için de uygundur. Sebze ve meyve üretimi ve çeşitliliği göreceli olarak Türkiye'nin diğer illerine göre daha azdır. Bunun yanında bölgenin hayvancılık için müsait olması Türkiye'nin önemli hayvancılık merkezleri arasında olmasını sağlamıştır. Bölgede toplum beslenmesinde özellikle et ve süt grubu besinleri yaygın olarak kullanılabilmektedir (Muş Ovası Tarım ve Hayvancılık Çalıştayı, 2017). Muş ilinin bu özellikleri mutfağına yansımıştır. İlin coğrafi işaretli ürünleri Muş Çorti Turşusu ve Muş Çorti Aşı'dır. Çorti bölgede yetişen lahanadan yapılan fermente bir besindir (Türk Patent ve Marka Kurumu, 2020). Bunun yanında yöresel yemekleri arasında Muş Köftesi, Kaburga Dolması, Yumurtalı Kenger, Jağ, Ayran Aşı, Kete bulunmaktadır (Saatcı, 2019: 364) . Muş Valiliği ilin yemek tanıtımında bunların yanında Pırvazi, Pınağun, Hazüt Dolması, Kırçikli Kelem Dolma, Teter Helvası, Kırçik, Keşkek, Herse, Mirtıge, Cavbelek, Helimaşi, Gülük, Kenger, Sıpidak, Uçkun ve Kak'dan bahsetmektedir (Muş Valiliği, 2020). Bu çalışmada Muş ilinin coğrafi işaretli ürünleri ve yöresel ana yemeklerinin beslenme antropolojisi çerçevesinde incelenmesi amaçlanmaktadır.

\section{Yöntem ve Uygulama}

$\mathrm{Bu}$ çalışmada Muş ilinin yöresel işaretli yemekleri ve geleneksel yemekleri, yemekleri oluşturan yemek malzemelerinin besin gruplarına ayrılarak antropolojik olarak incelenmesi planlanmıştır. Bölgenin coğrafi işaretli ürünleri Muş Çorti Turşusu ile Muş Çorti Aşı ve Belediyenin/Valiliğin sitelerinde gösterilen ve kent tanıtım broşürlerinde sıklıkla yer alan geleneksel ana yemekleri; Muş Köftesi, Kaburga Dolması, Yumurtalı Kenger, Hazüt (Hez) Dolması, Kırçikli Kelem Dolma, Cavbelek, Herse ve Kırçik çalışmaya dâhil edilmiştir. Çalışmaya dâhil edilen 10 ana yemeğin içerisindeki malzemeler et, süt, tahıllar/baklagiller, sebze ve diğer besin gruplarına göre ayrılmıştır.

\section{Bulgular}

Muş mutfağının ana yemeklerini oluşturan 10 yemek ve yemeklerin yapımında kullanılan malzemelerin listesi Tablo 1'de verilmiştir. Bu yemeklerin yapımında kullanılan malzemelerin et, süt, tahıl/baklagil, sebze ve diğer besin gruplarına göre dağılımı Tablo 2'de verilmiştir. Çalışmada 10 ana yemeğin tamamında hayvansal kaynaklar olan et ve/veya süt grubu ürünlerinin kullanıldığı görülmüştür. Altı yemeğin ana malzemesi ettir. Seçilen yemeklerin hiç birinde balık veya deniz ürünleri bulunmamaktadır. Süt ürünleri içinde tereyağı yemeklerin 6'sında kullanılırken süt/yoğurt grubu 3 yemekte kullanılmıştır. Kırçik dışındaki tüm yemeklerde tahıllar/baklagiller grubu kullanılmıştır. Bu grupta en fazla bölgede yaygın olarak yetişen buğday/bulgur kullanılmıştır. Muş Çorti Turşusu dışındaki tüm yemeklerde sebzeler ana malzeme olarak bulunmamaktadır. En fazla kullanılan sebze lahanadır. Muş Çorti Turşusu, Muş Çorti Aşı, Yumurtalı Kenger ve Kırçik yemeklerinde bitkiler salamura veya kurutma yöntemiyle hazırlanmış besinler kullanılmıştır. 
Tablo 1. Muş Coğrafi İşaretli ve Yöresel Yemekleri ile Yapılış Malzemeleri

\begin{tabular}{|c|c|}
\hline Yemek Ad1 & Yemek Malzemeleri \\
\hline Muş Çorti Turşusu & $\begin{array}{l}1 \text { adet büyük beyaz lahana (3-4 kg), } 280 \mathrm{~g} \text { kaya tuzu, 15-20 g pul biber, 15-20 g reyhan, } 1 \text { limon, su (kaynatılmıs), } \\
50 \mathrm{~g} \text { nohut }\end{array}$ \\
\hline Muş Çorti Aş1 & $1 \mathrm{~kg}$ Muş çorti turşusu, $750 \mathrm{gr}$ kuzu kol, $150 \mathrm{~g}$ yarma buğday, $60 \mathrm{~g}$ tereyağı, $20 \mathrm{~g}$ domates salçası \\
\hline Muş Köftesi & $\begin{array}{l}500 \text { g yağsız dana kıyma, } 1 \text { yumurta, } 1 \text { buçuk kâse ince bulgur, tuz / iç harcı için; } 4 \text { kuru soğan, } 1 \text { kaşık yağ, pul } \\
\text { biber, tuz, tereyağ } 1\end{array}$ \\
\hline Kaburga Dolmas1 & $\begin{array}{l}\text { 3-4 kg koyun veya keçi kaburgası, } 4 \text { su bardağı pilavlık bulgur, } 10 \text { yemek kaşığı tereyağı, } 2 \text { kaşık tuz, iç pilav için } \\
\text { istenen baharatlar }\end{array}$ \\
\hline Yumurtalı Kenger & $\begin{array}{l}3 \text { yumurta, } 2 \text { su bardağı süt, } 1 \text { su bardağı un, } 1 \text { su bardağ } 1 \text { doğranmış salamura kenger, } 1 \text { çay kaşı̆̆ tuz, kızartmak } \\
\text { için } 1 \text { çay bardağ1 ayçiçek yağ1 }\end{array}$ \\
\hline Hazüt (Hez) Dolması & 1 adet orta boy lahana, 500 gr yağlı kıyma, 2 su bardağı kırık pirinç, 1 su bardağı su, 1 tutam sumak \\
\hline Kırçikli Kelem Kolma & 1 kilo yağlı kıyma, 1 kâse ince bulgur, lahana, domates, biber, soğan, pul biber, tereyağı, tuz \\
\hline Cavbelek & Bulgur unu, yoğurt, sarımsak, soğan \\
\hline Herse & Kemiksiz et, buğday, tereyağı, tuz, baharat \\
\hline Kırçik & Kurutulmuş salatalık kabukları, yoğurt, soğan, sarımsak, biber, yağ \\
\hline
\end{tabular}

Tablo 2. Yemeklerin Besin Gruplarına Göre Malzeme Dağılımı

\begin{tabular}{|c|c|c|c|c|c|}
\hline Yemek Ad1 & Et Ürünleri & Süt Ürünleri & Tahıllar/ Baklagiller & Sebzeler & Diğer \\
\hline Muş Çorti Turşusu & - & Tereyağ & Nohut & $\begin{array}{l}\text { Lahana, Reyhan, } \\
\text { Limon }\end{array}$ & Kaya Tuzu, Pul Biber \\
\hline Muş Çorti Aş1 & Kuzu Eti & Tereyağ 1 & Yarma Buğday, Nohut & $\begin{array}{l}\text { Lahana, Reyhan, } \\
\text { Limon }\end{array}$ & $\begin{array}{l}\text { Kaya Tuzu, Pul Biber, } \\
\text { Salça }\end{array}$ \\
\hline Muş Köftesi & $\begin{array}{l}\text { Dana Kiyma } \\
\text { Yumurta }\end{array}$ & Tereyağ 1 & Bulgur & Soğan & Pul Biber, Tuz \\
\hline Kaburga Dolması & $\begin{array}{l}\text { Koyun veya Keçi } \\
\text { Kaburga }\end{array}$ & Tereyağ 1 & Bulgur & - & Tuz, Baharat \\
\hline Yumurtalı Kenger & Yumurta & Süt & Un & Kenger & Tuz, Ayçicek Yağı \\
\hline Hazüt (Hez) Dolması & Kiyma & - & Kırık Pirinç & Lahana & Sumak \\
\hline Kırçikli Kelem Kolma & Kiyma & Tereyağg1 & Bulgur & $\begin{array}{l}\text { Lahana, Domates, } \\
\text { Biber, Soğan }\end{array}$ & Tuz, Pul Biber \\
\hline $\begin{array}{l}\text { Cavbelek } \\
\text { Herse }\end{array}$ & - & Yoğurt & Bulgur Unu & Soğan, Sarımsak & \\
\hline Herse & Kemiksiz Et & lereyag1 & Bugday & & Tuz, Baharat \\
\hline Kırçik & - & Yoğurt & - & Sarımsak, Biber & Yağ \\
\hline
\end{tabular}

\section{Tartışma}

Bir bölgenin beslenme ve mutfak kültürü birçok faktörden etkilenmektedir. Bölgede yetişen tarımsal ürünler, bölgede yapılan hayvancılık, iklimsel özellikler, coğrafi şartlar, su kaynaklarının varlığı gibi faktörler beslenme şeklini etkilemektedir. Özellikle bölgedeki besinsel çeşitlilik ve besin kaynaklarının miktarı bölge mutfağının oluşmasını etkileyen ana faktörlerdendir (Düzgün ve Özkaya, 2015: 4243). Dünya mutfaklarına bakıldığında özellikle Mezopotamya, Hindistan ve Çin gibi tarımın ilk olarak başladığı bölgelerde yemek çeşitliliği oldukça yüksektir. Neolitik dönemde bu bölgeler ilkel bitkilerin ve evcilleştirilmeye müsait hayvanların bulunduğu yerlerdir. Ayrıca iklimsel koşullar tarım ve hayvancılık için müsaittir. $\mathrm{Bu}$ nedenle bu bölgeler insan nüfusunun arttığı ve medeniyetin inşa edildiği bölgelerdir. İnsan nüfusunun artması birçok gelişmeyi beraberinde getirmiş özellikle ticaretin gelişmesi ile besin çeşitliliği arttırılmıştır. Besin çeşitliliğinin artması da mutfak kültürünün gelişmesini sağlamıştır (Özbek, 2013). Anadolu coğrafyası da tarımın ilk başladığ 1 yerlerdendir. Bu bölgede hala ilkel buğday anası türleri bulunmaktadır. Üstelik bölgedeki buğday çeşitliliği oldukça yüksektir (Özberk vd., 2016). Anadolu coğrafyasında yapılan arkeolojik kazılarda birçok bölgede farklı hayvan kemikleri bulunmuş ve bu hayvanların avlanıp yenildiği görülmüştür. $\mathrm{Bu}$ bölgede çok uzun zamandır hayvansal kaynakların tüketimi gerçekleşmektedir (Eren ve Özer, 2018: 309). Anadolu'da iklim koşullarının uygun olması, yabani bitki ve hayvanların bulunması bu bölgenin besin çeşitliliği açısından zengin bir yer olmasını sağlamıştır. Bu çeşitlilik birçok medeniyetin kurulmasına neden olmuş ve kurulan medeniyetler de bölgenin sosyal ve ekonomik açıdan gelişmesini sağlamıştır. Böylece Anadolu mutfağı dünyanın en zengin mutfakları arasında yer almıştır. Anadolu mutfağının bu kadar geniş olmasında ana etken coğrafi ve iklimsel koşullardır.

Doğu Anadolu Bölgesi’nde yer alan Muş yazların kısa kurak ve serin, kışların ise uzun, soğuk ve bol kar yağışlı geçtiği karasal iklime sahip bir ildir. Bölgede tarım ürünleri çok fazla çeşitlilik göstermemekle birlikte yetişen ürünler genelde soğuğa karşı dayanıklı bitkilerdir. Muş'un büyük bölümü yükseltisi fazla olan dağlık arazilerden oluşmaktadır. Muş il sınırları içerisinde ki yerleşmelerin \%2'si 1000-1250 m, \%39'u 1250-1500 m, \%39'u 1500$1750 \mathrm{~m}, \% 17$ 'si 1750-2000 m, \%3'ü 2000-2250 m yükseklikte yer almaktadır. Ovaların da yükseltisi fazladır. Tarım alanlarının yaklaşık olarak yarısı atıl durumdadır. Ayrıca tarım arazilerinin sadece \%59'u sulanabilmektedir (Ersungur ve Aslan, 2014: 2020-228; Dölek ve Harunoğulları, 2018: 1011). Muş bölgelerine göre sıcaklık ve yağış farklılıkları da gösterebilmektedir. Özellikle tarımsal üretim için önemli merkezler olan Malazgirt ve Bulanık'ta yıllık yağış miktarı ve ortalama sıcaklık 
farklılıkları görülmektedir. $\mathrm{Bu}$ nedenle ilçelerine göre tarımsal üretim miktarları da değişmektedir (Şengün ve Kıranşan, 2016: 21). Bölgenin toplam tarla alanı 2.362.346 dekar ve toplam çiftçi sayısı 17.326 kişidir. Halkın yaklaşık \%60’1 kırsal kesimde yaşamaktadır. Bölgede yıllık yetişen ürünlerin başında tarla bitkileri olan buğday (244.499 ton), arpa (37.310 ton), şekerpancarı (125,303 ton), aspir (3.415 ton) ve patates (4.349 ton) gelmektedir. $\mathrm{Bu}$ ürünlerin üretimi yaklaşık 422 bin ton olup ülke genelinde üretimin $\% 0,66$ 'sı kadardır. Meyvelerin başında üzüm (2.157 ton), elma (1.352 ton), çilek (648 ton), ceviz (572 ton) ve armut (545 ton) üretimi toplamda 5,6 bin ton olup ülke genelindeki üretimin \%0,03'üne karş1lık gelmektedir. Sebzelerin başında ise karpuz (60.896 ton), domates (32.552 ton), kavun (17.120 ton), lahana (10.833 ton), hiyar (9.560 ton) üretimi de toplamda yaklaşık 138 bin ton olup ülkedeki üretimin \%0,44'ü kadardır. Genel olarak bakıldığında ilde 2019 yllında toplam meyve üretimi 5.589 ton, sebze üretimi 138.157 ton ve tarla bitkisi üretimi 421.587 tondur. Ayn1 zamanda Türkiye'deki yem üretiminin \%78'i bu bölgeden karşılanmaktadır (Tarım ve Orman Bakanlığı, 2019: 1-6) Son yıllarda Muş ilinde nüfusun artması ve tarım gelirlerinin düşmesi üzerine kırsal kesimden şehirlere doğru göçler başlamış ve tarıma olan ilgi azalmaya başlamıştır (Yıldırım, 2014: 28). Bunun yanında Muş ilinde konvansiyonel tarımın uzun süre yapılmamış olması bölgenin organik tarım açısından elverişli imkânlara sahip olduğunu göstermektedir (Arslan, 2018: 76). Aynı zamanda bölgede besin olarak tüketilen çeşitli endemik otlar bulunmaktadır (İyigün ve Özer, 2001: 66). Muş ilinin iklimsel ve coğrafi koşulları göz önüne alındığında her dönem yüksek tarımsal verimliliğe sahip olmadığı ve tarımsal besin çeşitliliğinin fazla olmadığı görülmektedir. Bölgedeki başlıca tarım ürünü tahıllardır. Bu özelliği bölgesel yemeklere de yansımıştır. Çalışmamızda görüldüğü gibi 10 geleneksel Muş yemeğinden 8'i tahıl içermektedir. Aynı zamanda tahıllar ekmek olarak da tüketilmektedir. Türkiye'nin diğer bölgeleri göz önüne alındığında sebze yemekleri Muş'un önemli yemekleri arasında geniş yer tutmamıştır. Bunun yanında lahana bölgenin en önemli sebze kaynağı olup coğrafi işaretli yemekler olan Muş Çorti Aşı ve Muş Çorti Turşusu'nun ana malzemesidir. Muş yemeklerinin sebze ve meyve açısından zengin olmayışının temel nedeni bölgedeki tarımsal üretimin yüksek verimlilik ve çeşitliliğe sahip olmamasıdır.

Sebzeler ve meyveler sağlığın desteklenmesi ve sürdürülebilmesi açısından önemli besin grubudur. Bu grup, vitamin, mineral, biyoaktif maddeler ve posa açısından zengindir. $\mathrm{Bu}$ içeriklerinden dolayı obezite, diyabet, kardiyovasküler hastalıklar, kanser veya otoimmün hastalıklar gibi birçok hastalıktan koruyucu etki göstermektedir (T.C. Sağlık Bakanlığı Halk Sağlığı Kurumu, 2016). Muş ili yemeklerinde sebzenin az oranda kullanılması ve bölgede meyve çeşitliliğinin yüksek olmaması nedeniyle beslenmeye bağlı kronik hastalıklar için risk taşıdığ 1 görülmektedir. Bunun yanında bölgede yetişen endemik bitkilerin yemeklerde kullanılmasının bu riski azaltabildiği düşünülmektedir. Bölgede sebze veya meyve üretimini arttıracak faaliyetlerin zenginleştirilmesi gerekmektedir. Böylece bölge halkının mutfak kültürüne daha fazla sebze içeren besinlerin girebileceği düşünülmektedir.
Muş tarihi boyunca bu bölgenin en önemli geçim kaynağ hayvancılık olmuştur (Tiryaki, 2019: 77). Bölgenin hayvancılık için geniş ve doğal mera alanlarına sahip olması bölge halkı için ekonomik firsat oluşturmaktadır. Günümüzde de bölgede tarım koşullarının çeşitlilik ve ekonomik getiri açısından çok uygun olmaması halkı özellikle hayvancılığa yönlendirmiştir (Ersungur ve Aslan, 2014: 213). Bölgede hayvancılığın büyük kısmı geleneksel yöntemlerle yapılmaktadır. Bu nedenle hayvansal üretim verimliliği düşüktür (Şeker vd., 2012: 9). Bölgede 2019 yılında toplam 317.989 sığır, 7.078 manda, 870.338 koyun ve 214.253 keçi yetiştirilmiştir. Toplamda 1.409 .658 hayvan ile bölgenin hayvancılık açısından Türkiye'nin önemli merkezlerinden olduğu görülmektedir. Büyükbaş hayvan sayısı açısından Türkiye'de 17. sırada, küçükbaş hayvan sayısında 12 . sırada ve manda yetiştiriciliğinde 6 . sıradadır. Bu durum hayvansal besin kaynakları olan et ve süt grubunun bölge için önemli olduğunu göstermektedir. Y1llı 354 bin ton süt ve 9.419 ton kırmızı et üretilmektedir (Tarım ve Orman Bakanlığı, 2019: 7-10). Çalışmamızda bölge yemeklerine bakıldığında yemeklerin büyük bölümünün et ağırlıklı olduğu görülmüştür. Bölgede halkın büyük kesiminin kırsalda ve hayvancılıkla uğraşıyor olması temel besin kaynağını et olarak şekillendirmiştir.

Hayvancılığın yaygın olduğu bölgelerde önemli bir besin kaynağı da süt ve süt ürünleridir. Kırsal kesimde özellikle peynir ve yoğurt tüketimi yüksek oranda olmaktadır (Çiftçi vd., 2010: 1-7). Yapılan bir çalışmada Muş bölgesindeki 346 süt işletmesi incelenmiş, süt sağımının günde iki kez elle yapıldığı ve ortalama bir hayvanın 7,4 ay sağıldığ bulunmuştur. İşletmelerin yarısından fazlası günlük süt veriminin 6 ile $10 \mathrm{~kg}$ arasında değiştiği bildirilmiştir. Üretilen sütün \%70,5'inin yoğurt, tereyağ1 ve peynir için kullanıldığ 1 bulunmuştur. Küçük işletmelerde ise üretilen süt ürünlerinin sadece üreticilerin ihtiyaçları için kullanıldığı bildirilmiştir. Daha büyük işletmeler ise üretimin \%10-15'ini kendi tüketimleri için kullanmaktadır (Bakır ve Kibar, 2019a: 620). Muş ilinde üretilen süt ürünlerinin kalitesi ve Türk Gıda Kodeksi'ne uygunluğu araştırıldığında üretilen ürünlerin uygun olduğu ve sağlık açısından risk barındırmadığ 1 görülmüştür (Gökmen ve ark., 2013: 36). Bunun yanında süt üretimi yapılan tesislerde yerli ve melez türlerin sayısının farklı olması, ekonomik nedenler ve veteriner hizmetlerine ulaşım nedenleriyle üretim verimliliğinin değiştiği bildirilmiştir (Bakır ve Kibar, 2019b: 609). Çalışmamızda özellikle süt grubunun tereyağı yapılarak yemeklerde sıklıkla kullanıldığı görülmüştür. Aynı zamanda Çavbelek, Kırçik ve Yumurtalı Kenger yemeklerinde besin içeriğinin zenginleşmesi için yoğurt veya ayran şeklinde kullanılmaktadır. Bu özellikler hayvancılığa dayalı beslenme şeklini yansıtmaktadır.

Muş ili deniz ve göller açısından zengin olmayıp Alparslan 1 ve Alparslan 2 Barajları ile Murat Nehri'nde balıkçılık yapılabilmektedir. Bölgede yıllık 3.115 ton alabalık üretilmektedir (Tarım ve Orman Bakanlığı, 2019: 11). Doğu Anadolu Bölgesi iç su kaynakları, su ürünleri üretim potansiyeli açısından Türkiye'de birinci sırada olmasına rağmen Muş ilinde su ürünleri kooperatif sayısı bu bölgenin \%2'si kadardır. Toplam balıkçı sayısı 15 olup Doğu Anadolu Bölgesi içinde toplam balıkçıların \%1'inden azdır (Mesut ve Canpolat1, 2009: 373-378). Bölgede balıkçılık imkânlarının sınırlı olması Muş mutfağına da yansımıştır. 
Muş mutfağının önemli yemekleri arasında balık yemekleri bulunmamaktadır.

Muş ili yemekleri incelendiğinde bölge yemeklerinin büyük bölümünün hayvansal kaynaklardan sağlandığı görülmektedir. Et grubu besinleri özellikle yüksek kalite protein ve yağdan zengin oldukları gibi niasin, tiamin, riboflavin, B6, B12 ve E vitamini gibi vitaminler ile demir, çinko ve magnezyum gibi mineraller açısından da zengindir. Süt ve ürünleri ise yüksek kalitede protein ve yağ yanında kalsiyum, fosfor, çinko gibi mineraller ve tiamin, riboflavin, B6, B12 ve niasin gibi vitaminlerden zengindir. $\mathrm{A}, \mathrm{D}, \mathrm{E}$ ve $\mathrm{K}$ vitaminleri süt yağında bulunmaktadır. Özellikle çocuklar, gençler, kadınlar ve yaşlıların her gün süt ürünü tüketmesi önerilmektedir. Aynı zamanda hayvansal kaynaklar yüksek enerji içermektedir. Bu nedenle bu besinlerin tüketiminin yaygın olması beslenme yetersizliklerini azaltmaktadır (T.C. Sağlık Bakanlığı Halk Sağlığı Kurumu, 2016). Bunun yanında hayvansal kaynakların doymuş yağ oranı yüksektir. Fazla miktarda hayvansal besinlerin tüketimi ve bunun yanında sebze ve meyve tüketimi azlığı kalp-damar hastalıkları açısından risk oluşturmaktadır (Persil Özkan vd., 2018). Bölge halkının kalp damar hastalıklarını önleme açısından oldukça önemli yağ asitlerini içeren balık tüketim miktarı da düşüktür. Bu nedenle bölge için yemeklerde yağsız etlerin kullanılması, pişirme sırasında ilave yağ kullanılmaması, pişirme tercihlerinde kızartma veya mangal yerine buharda pişirme veya haşlama tercih edilmesi aynı zamanda balık yetiştiriciliği ve balık tüketiminin teşvik edilmesi gerekmektedir. Özellikle yüksek fiziksel aktivite gerektiren kırsal yaşam koşullarından şehre göçlerin artması sedanter yaşama neden olabilmektedir. Bölge halkının şehre göçü ile fiziksel aktivite durumunun azalıp, beslenme kültürlerinde bu değişiklikleri yapmazlarsa bölgede kalp-damar sağlığ açısından riskin artacağı düşünülmektedir.

Belirli bir bölgede yaşayan medeniyetler o bölgenin beslenmesi üzerinde de izler bırakmaktadır. $\mathrm{Bu}$ izler zamanla birçok farklı medeniyeti etkileyerek bu etkinin yayılmasını sağlamaktadır (Muslu, 2019: 2). Örnek olarak eski Anadolu uygarlıklarında testi, çömlek, gügüm ve kap kaçak gibi kullanılan mutfak eşyalarının yapılışı ve süslenişi günümüzde birçok köyde aynı şekilde devam etmektedir. Aynı zamanda bölgelere ait yemekler genelde geçmiş medeniyetlerde de sıklıkla yapılan veya benzer yemeklerdir. Yemeklerin isimleri de geçmiş veya yakın ilişkiler kurulmuş medeniyetlerden etkilenebilmektedir (Şensoy ve Tiritoğlu, 2018). Yakın bölgelerde yaşamış olan Türkler ve Ermenilerin yemeklerinin birçoğu birbirine benzemektedir. Keşkek her iki kültürde de ortaktır. Yine sıklıkla Doğu Anadolu mutfağında tüketilen kete, Ermeniler tarafindan khorsovhats ismiyle yapılıp tüketilmektedir. İstanbul'da yaşayan birçok farklı etnik grup benzer yemeklere sahiptir. Türklerin "aşure", Ermenilerin "anuşabur", Rumların "koliva" ve Yahudilerin "trigo koço" olarak adlandırdığı tatlı aslında içerik olarak ve kültürel anlamda hikâyelerinin olması açısından benzemektedir (Döner, 2019). Muş’un Malazgirt Bölgesi Türklerin Anadolu'ya girdiği yerdir. Bu nedenle bu bölge uzun zaman geçiş bölgesi olmuş ve özellikle göçebe Türklerin uğrak yeri olmuştur. Muş çevresine göçlerle yerleşmiş olan TerekemeKarapapak Türkleri hem kendi mutfak kültürleri ile bölgeyi etkilemiş hem de bölgenin mutfak kültüründen etkilenmiştir (Kemaloğlu, 2011: 248). Bazı yemekler bölgede yaşayan etnik grupların veya milletlerin ismi ile anılmaktadır. Laz Böreği, Tatar Böreği, Kürt Pilavı, Muhacir Somunu, Muhacir Böreği, Çerkez Salatası, Çerkez Tavuğu, Çerkez Abıstası, Özbek Pilavı, Acem Pilavı, Arabaşı, Abaza Peyniri, Yörük Kebabı, Çingene Pilavı, Arapsaçı, Arnavut Böreği, Firenk Kebabı gibi yemekler bu konuda verilecek örneklerdendir (Fırat, 2014). Çalışmamızda yer alan Muş Çorti Aşı, Muş Çorti Çorbası ve Muş köftesi bu bölgenin hazırlanma, pişirilme ve tüketilme şekline bağlı olarak bölge ismi ile anılmaktadır.

Muş’un tarihi ilk çağlarda Urartulara kadar dayanmaktadır. İlin çevresinde de bulunan geniş alanlar Hurriler, Mitaniler, Urartular, Asurlular, Kimriler, Medler, Ermeniler, Makedonyalılar, Firikyalılar, Persler, Romalılar, Bizanslılar, Karakoyunlular, Akkoyunlular ve Büyük Selçuklu Devletinin hâkimiyeti altına girmiştir (San, 1966: 127-203; Tiryaki, 2019: 81-108). Bir bölgede hüküm süren medeniyetler bölgeyi sosyokültürel anlamda etkilemektedir. Bölgenin mutfağı ve yemek isimleri de bu medeniyetlerden etkilenmektedir. İran üzerinden Anadolu'ya girmiş olan birçok besin ismi Farsça kökenden gelmektedir. Farsça sarıerik (zerd-alu) anlamına gelmekte olan kayısı bazı bölgelerde zerdali olarak bilinmektedir. Tombul erik (şeft-alu) anlamına gelen şeftali, sütten yapılmış anlamına gelen (panir) peynir, tuzlu yemek (şor; tuzlu, bulanık / ba; yemek, aş) anlamına gelen çorba da aynı kökenden gelmektedir. Yunanca Karadenizli (pontika) anlamına gelen findık, yeşil anlamına gelen (prassino) pırasa ve meyve (karpos) anlamına gelen karpuz da farklı kültürlerin izlerini taşımakta olup dilimize yerleşmiştir (Tez, 2012; 137). Çalışmamızda Muş Çorti Turşusu, Muş Çorti Aşı, Hazüt Dolması ve Kırçikli Kelem Dolma'nın malzemesi olan ve Anadolu'da kelem olarak da adlandırılan lahana, Yunanca sebze anlamina gelen lakhanon kelimesinden gelmektedir (Baydur, 1999). Muş ilinin geniş bir tarihe sahip olması geleneksel yemeklerinin yapılış tarzından yemek isimlerine kadar etki göstermiştir. Çorti, Hazüt, Kırçik, Kenger gibi bu bölgenin geçmişine dayanan yemek isimleri farklı kültürden gelmektedir.

Çalışmamızda Muş Çorti Turşusu, Muş Çorti Aşı, Yumurtalı Kenger ve Kırçik gibi yemeklerde salamura sebzelerin kullanıldığı görülmektedir. Neolitik dönemden bu yana bu bölgede özellikle sebzelerin kışa hazırlanması için kurutma veya salamura yöntemi kullanılmaktadır. Bu sayede kışların sert geçtiği bu bölgede insanlar bazı sebze ve meyve türlerini tüketebilmişlerdir. $\mathrm{Bu}$ uygulamalar geçmişten izler taşıyarak günümüze kadar gelmiş ve bölge mutfağını etkilemiştir. Bugün hala Muş gibi kışların soğuk geçtiği birçok bölgede farklı sebze ve meyveler kurutularak ya da salamura edilerek saklanmaktadır.

Bölgesel yemeklerin ve mutfak kültürünün oluşmasında çevresel ve ekonomik şartlar dışında sosyokültürel etmenler de büyük önem taşımaktadır (Beşirli, 2012: 12-23). Özellikle beslenme ile ilgili sosyokültürel yaklaşımın temellerinde dini inançlar yatmaktadır. Türkiye İslam dininin yaygın olduğu bir ülkedir ve temel beslenme şekilleri genelde bu çerçevede oluşmuştur. Kuran-1 Kerim Müslümanlar için yenmesi yasak olan besinleri açık bir şekilde belirtmiştir. Bunların başında domuz, leş, kan, Allah adına kesilmeyen hayvan ve alkol gelmektedir (Şensoy, 2020: 105). Dini değerlerle uyuşmayan ürünlerin toplum tarafından tüketilmemesi veya böyle ürünler bulunduğunda 
tüketilmemesi için boykot edilmesi yaygın gözlenen bir durumdur (Uysal ve Cömert, 2017: 102). Dünya üzerinde farklı mutfaklarda etlerin alkol ile marinasyonu veya et olarak domuz eti tüketimi yaygın görülmektedir. Geleneksel Anadolu mutfağında ise bu durumlar birer tabudur. Çalışmamızda görüldüğü gibi Muş ilinin geleneksel yemeklerine bakıldığında İslam dininin yasakladığı hiçbir ürün yemeklerde kullanılmamıştır. Bu durum dinin beslenme kültürünün oluşmasında ne kadar etkin olduğunun göstergesidir.

\section{Sonuç}

Muş ili sert iklim koşulları ve yükseltisi nedeniyle sebze ve meyve çeşitliliğinin çok yüksek olmadı̆̆ı bunun yanında hayvancılığın oldukça yaygın olarak yapıldığı bir ildir. Bölgenin temel ekonomik kaynaklarının hayvancılığa dayalı olması bölge mutfağının şekillenmesinde ana faktör olmuştur. Bölgeye ait özel yemeklerin büyük çoğunluğu hayvansal kaynakla et ve süt grubuna dayanmaktadır. Balıkçılığın yaygın olmaması bölgede balık yemeklerinin önemli yemekler arasına girmesini engellemiştir. Bölgede yetişen lahana en önemli sebze kaynaklarından olup coğrafi tescilli Muş Çorti Turşusu ve Muş Çorti Aşı’nın temel malzemesidir. Aynı zamanda bölgede çok eskilere dayanan geleneksel besin saklama yöntemleri olan kurutma ve salamura kullanılmaktadır. Yemek isimleri bölgenin önceki medeniyetlerinin etkilerini taşımaktadır. Günümüzde bölgedeki en yaygın dinin İslam olması yemeklerin İslami usullere uygun olmasını sağlamıştır. Bölgenin mutfağının sağlık açısından riskli yanları özellikle hayvansal tüketimin fazlalığına dayanan yüksek doymuş yağ alımı ve sebzemeyve çeşitliliğinin azlığıdır. Bu nedenle bölgede balıkçılık ve meracılığın geliştirilmesi gerekmektedir.

\section{Kaynakça}

Arslan, Ö. (2018). Muş ili özelinde doğal tarım ve hayvancılığa dayalı sürdürülebilir bir ekonomik gelişim. Anemon Muş Alparslan Üniversitesi Sosyal Bilimler Dergisi, 6(1), 75-90.

Bakır, G., \& Kibar, M. (2019a). Muş ilinde özel süt sığırcılığ1 işletmelerinde süt verim özelliklerinin belirlenmesi. Kahramanmaraş Sütçü Imam Üniversitesi Tarım ve Doğa Dergisi, 22(4), 620-630.

Bakır, G., \& Kibar, M. (2019b). Muş ilinde bulunan süt sığırcılığı işletmelerinin bazı yapısal özelliklerinin Crostabb analiziyle belirlenmesi. Kahramanmaraş Sütçü Imam Üniversitesi Tarım ve Doğa Dergisi, 22(4), 609-619.

Baydur, S. Y. (1999). Dil ve kültür. İstanbul: Cumhuriyet Gazetesi Yayınları.

Baysal, A. (2017). Beslenme. Ankara: Hatipoğlu Yayınevi.

Beşirli, H. (2012). Yemek sosyolojisi: yiyeceklere ve mutfağa sosyolojik bakış. Ankara: Phoenix Yayınevi.

Çiftçi, K., Şahin, A., Deniz, A., \& Yıldırım, İ. (2010, Eylül). Hakkâri ili merkez ilçe kentsel ve kırsal alanda süt ve ürünleri tüketim yapısı. Türkiye IX. Tarım Ekonomisi Kongresi, Şanlıurfa.

Dölek, İ., Avcı, V., \& Harunoğulları, M. (2018). Nüfusun ve yerleşmelerin yükseltiye göre değişimi: Muş ili örneği. Anemon Muş Alparslan Üniversitesi Sosyal Bilimler Dergisi, 6(6), 1011-1022.

Döner, B. (2019). Azınlıkların gündelik yaşamında kültürel süreçler: İstanbul örneği (Moda, Tatavla, Samatya, Burgazada) (Yayımlanmamış doktora tezi). Kocaeli Üniversitesi Sosyal Bilimler Enstitüsü İletişim Anabilim Dalı, Kocaeli.

Düzgün, E., \& Özkaya, F. D. (2015). Mezopotamya'dan günümüze mutfak kültürü. Journal of Tourism and Gastronomy Studies, 3(1), 41-47.

Eren, E., \& Özer, İ. (2018). Eski Anadolu toplumlarında beslenme alıskanlıkları. Güncel Turizm Araştırmaları Dergisi, 2(Ek1), 308-323.

Ersungur, Ş., \& Aslan, M. (2014). Muş ilinin gelişme potansiyelinin SWOT analizi ile incelenmesi. Atatürk Üniversitesi İktisadi ve İdari Bilimler Dergisi, 28(4), 213-235.

Fırat, M. (2014). Yemeğin ideolojisi ya da ideolojinin yemeği: Kimlik bağlamında yemek kültürü. Folklor/Edebiyat, 20(80), 129-140.

Gökmen, S., Çağlar, A., \& Yetim, H. (2013). Muş ilinde tüketime sunulan bazı süt ürünlerinin güvenilirliği üzerine bir araştırma. Cumhuriyet Üniversitesi FenEdebiyat Fakültesi Fen Bilimleri Dergisi, 34(2), 3648.

İyigün, Ö., \& Özer, Z. (2001). Muş ve yöresinde gıda olarak kullanılan yabanc1 otlar. Türkiye Herboloji Dergisi, 4(2), 66-73.

Kemaloğlu, M. (2011). Terekeme-Karapapak türkleri ve yemek kültürü (Muş-Bulanık çevresinde). Erzincan Üniversitesi Sosyal Bilimler Enstitüsü Dergisi, 4(2), 415-438.

Mead, Margaret. (1970). The changing significance of food: a discussion of the interrelationship between the diet of Americans and their capacity to provide for the poor and starving at home and abroad. American Scientist, 58, 176-81.

Merdol, T. K. (2015). Beslenme antropolojisi 1. Ankara: Hatipoğlu Yayınevi

Mesut, U., \& Canpolatı, İ. (2009). Doğu ve Güneydoğu Anadolu bölgelerindeki su ürünleri kooperatiflerinin yapısı ve av araçları ile balıkçı teknelerinin teknik özellikleri. TÜBAV Bilim Dergisi, 2(4), 372-384.

Muslu, M. (2019). Beslenmenin tarihsel süreçte sosyal ve uluslararası ilişkilere yansıması. Sosyologca Dergisi, 17, 25-30.

Muş Ovası Tarım ve Hayvancılık Çalıştayı (2017). Muş Ovası Tarım ve Hayvancılık Çalıştayı Kitabı 16-17 Mayıs. Muş: Muş İl Gıda Tarım ve Hayvancılık Müdürlüğü. 
Muş Valiliği. (2020). Mahalli Yemekler. (Erișim Tarihi: 10.09.2020) http://mus.gov.tr/mahalli-yemeklermus

Özbek, M. (2013). Beslenme kültürü ve insan: Niçin săglıklı besleniriz? Ankara: Alter Yayıncılık.

Özberk, F., Karagöz, A., Özberk, İ., \& Atlı, A. (2016). Buğday genetik kaynaklarından yerel ve kültür çeşitlerine; Türkiye'de buğday ve ekmek. Tarla Bitkileri Merkez Araştırma Enstitüsü Dergisi, 25(2), 218-233.

Persil Özkan, Ö., Büyükünal S.K., Yiğit Z., Erginbaş Ç. \& Şakar F.Ş. (2018). Kardiyovasküler hastalık tanısı almış hastaların genel beslenme bilgi düzeylerinin değerlendirilmesi. Journal of Current Researches on Health Sector, 8(2), 195-208.

Richards, A. (1932). Hunger and work in a savage tribe: A functional study of nutrition among the Southern Bantu. London: Routledge \& Kegan Paul.

Richards, A. (1939). Land, labour, and diet in Northern Rhodesia: an economic study of the Bemba Tribe. Oxford: Oxford University Press.

Saatcı, G. (2019). Coğrafi işaretli yiyeceklerin tanıtım unsuru olarak yöresel yemekler kapsamında değerlendirilmesi. Journal of Tourism and Gastronomy Studies, 7(1), 358-374.

San, M. S. (1966). Doğu Anadolu ve Muş'un izahlı kronolojik tarihi. Ankara: Yargıçoğlu Matbaası.

Sönmez, M. (2010). Muş ilinde nüfus hareketlerinin nedenleri ve sonuçlar1. Türk Coğrafya Dergisi, (55), 45-57.

Şeker, İ., Tasalı, H., \& Güler, H. (2012). Muş ilinde sığır yetiştiriciliği yapılan işletmelerin yapısal özellikleri. Furat Üniversitesi Sağlık Bilimleri Veteriner Dergisi, 26(1), 9-16.

Şengün, M. T., \& Kıranşan, K. (2016). Bulanık-Malazgirt (Muş) Havzası'nın iklim özellikleri. Bingöl

$$
\begin{aligned}
& \text { Üniversitesi Sosyal Bilimler Enstitüsü } \\
& \text { Dergisi, 6(12), 21-50. }
\end{aligned}
$$

Şensoy, F. (2020). Dinler ve Beslenme. İçinde: Tek, N.A. ve Sürücüoğlu, M.S. (ed). Beslenme Antropolojisi (s.78-109). Ankara: Hedef CS Basın Yayın.

Şensoy, F., \& Tiritoğlu, S. (2018). Beslenme arkeolojisi: Günümüz ankara yemeklerinde geçmişin izleri. Güncel Turizm Araştırmaları Dergisi, 2(Ek1), 209-233.

Tarım ve Orman Bakanlığı. (2019). Muş Tarımsal Yatırım Rehberi. (Erişim Tarihi: 10.09.2020) https://www.tarimorman.gov.tr/SGB/TARYAT/Bel geler/il_yatirim_rehberleri/mus.pdf

Tez, Z. (2012). Lezzetin tarihi: geçmişten bugüne yiyecek, içecek ve keyif vericiler. İstanbul: Hayykitap.

Tiryaki, S. (2019). Eski Çağ'da Muş. Igdir University Journal of Social Sciences, (19), 75-114.

T.C. Sağlık Bakanlığı Halk Sağlığı Kurumu. (2016). Türkiye Beslenme Rehberi 2015. (s.1-288). Ankara.

Türk Patent ve Marka Kurumu. (2020). Türkiye’nin Coğrafi Işsaretleri. (Erişim Tarihi: 10.09.2020) https://www.ci.gov.tr/

Ulijaszek, S. (2018). Nutritional anthropology. The International Encyclopedia of Anthropology, 110. doi:10.1002/9781118924396.wbiea1510.

Ulijaszek, S. \& Strickland, S.S. (1993). Nutritional anthropology: Prospects and perspectives. London: Smith-Gordon.

Uysal, A., \& Cömert, Y. (2017). Tüketici boykotu katılım güdüleri: Muş ili örneği. Akademik Yaklaşımlar Dergisi, 8(1), 97-125.

Yıldırım, A. (2014). Kırsaldan kente göç ve değişen siyaset: Muş örneği. Karamanoğlu Mehmetbey Üniversitesi Sosyal ve Ekonomik Araştırmalar Dergisi, (3), 2532. 